\title{
Studi Kepuasan Konsumen Pada Peacock Coffee Gajah Mada Semarang
}

\author{
Tuwuh Adhistyo $\mathrm{W}^{1}$, Krisnawati Setyaningrum $\mathrm{N}^{2}$ \\ ${ }^{12}$ Sekolah Tinggi Ilmu Ekonomi Pariwisata Indonesia \\ Email: zefanya.adhistyo@gmail.com
}

\begin{abstract}
Coffee shop involved contribute in tourism sector especially for specific customer in coffee. Coffee shop growing fast following international tren. Differencies theme and concept are designed to attract customer and increase the customer satisfaction. Start from the raw material, variety of coffee product and side dish to complete the package. The owner design this concept carefully. This research head for detect the customer satisfaction influence factors.

This research use non-probability sampling method, with unpredicted customer in Peacock Coffee. For Sampling derivation use Accidental sampling at 87 persons. Result of the analize support all of the suggest hypotize. Product quality, facilites and location have partially effect nor simultant to the customer satisfaction, and location becomes the dominant influence.
\end{abstract}

Keywords : Product quality, Facilities, Location

Abstrak

Coffee Shop saat ini merupakan salah satu faktor pendukung dalam sektor pariwisata, dimana mereka memiliki peminat khusus. Khususnya para konsumen yang tertarik pada cita khas rasa kopi yang unik. Perkembangan bisnis Coffee shop saat ini paling cepat di dunia dan menjadi tren. Berbagai gaya dan tema bermunculan untuk masing-masing coffee shop untuk menarik dan memberikan kepuasan pada konsumen. Mulai dari bahan baku kopi yang digunakan, create kreasi menu coffee yang ditawarkan serta menu makanan pendamping coffee. Semuanya dipikirkan betul-betul oleh pemilik usaha. Penelitian ini bertujuan untuk mengetahui faktor-faktor yang mempengaruhi kepuasan konsumen.

Metode yang digunakan metode non-probality Sampling dikarenakan jumlah pengunjung Peacock Coffee tidak diketahui dengan pasti. Metode pengambilan sampel yang digunakan Accidental sampling dengan jumlah sebanyak 87 sampel. Hasil analisis data dalam penelitian mendukung semua hipotesis yang diajukan. Kualitas produk, fasilitas dan lokasi mempunyai pengaruh secara parsial maupun simultan terhadap kepuasan konsumen dan variabel lokasi mempunyai pengaruh dominan.

Kata kunci: Kualitas Produk, Fasilitas dan Lokasi

(C) 2020 Jurnal Riset Inspirasi Manajemen dan Kewirausahaan

\section{PENDAHULUAN}

Apabila pariwisata dilihat sebagai suatu usaha yang memiliki nilai ekonomi, maka pariwisata merupakan suatu proses yang dapat memberikan nilai tambah terhadap suatu barang atau jasa baik itu tangible maupun intangible. Sebagaimana yang kita ketahui pariwisata merupakan salah satu bidang yang menjadi sumber devisa negara terbesar selain sektor-sektor ekonomi yang lain. Pariwisata juga melibatkan sektor-sektor pendukung yang lain seperti transportasi, akomodasi, perdagangan dan lain-lain. Karena semua sektor ini mendukung perkembangan dari pariwisata itu sendiri. Sektor pariwisata mempunyai kedudukan yang cukup strategis dalam dinamika pembangunan di Indonesia. Hal ini diperkaya dengan keragaman warisan budaya lokal yang hidup dan terpelihara ditengah masyarakat dari dahulu hingga kini dan kekayaan yang dimiliki itu harus diiringi dengan pengembangan dan pemeliharaan serta melengkapi fasilitas yang ada di obyek tersebut.

Coffee Shop juga merupakan salah satu faktor pendukung dalam sektor pariwisata, dimana mereka memiliki peminat khusus. Coffee Shop khususnya mampu memikat para konsumen dengan ketertarikan tersendiri pada kopi. Dengan berkembangnya budaya atau tren minum kopi pada masyarakat secara umum, maka semakin pesat pekembangan dari industri ini. Persaingan bisnis pada dunia restoran, kafe, bar serta Coffee Shop ini semakin meningkat, mereka memberikan keunggulan masing-masing. Persaingan bisnis dalam bidang usaha Coffee Shop yang menyediakan ragam kopi yang bisa dinikmati oleh para pecintanya tentu semakin tinggi pula, mereka pun 
berlomba untuk memberikan produk yang terbaik dengan cara pengolahan yang berkualitas pula.

Untuk menghadapi persaingan tersebut, Coffee Shop harus mampu meningkatkan semuanya, baik dari segi kualitas produk yang dijual, fasilitas yang diberikan kepada tamu, maupun pengelolaan lokasi tersebut. Memberikan kualitas produk yang terbaik tentu menjadi salah satu syarat utama dalam bisnis ini, dimana konsumen selalu berharap untuk mendapatkan layanan yang terbaik sehingga mereka akan mendapatkan kepuasan. Fasilitas sebagai sarana pelengkap pun harus mendapatkan yang khusus, hal ini disebabkan karena lama tidaknya konsumen berada di venue juga disebabkan fasilitas yang diberikan atau yang disediakan. Semakin lengkap dan memadahinya fasiltas yang ada, maka konsumen akan semakin merasa di manjakan dan membuat mereka semakin betah dan enggan untuk beralih pada tempat yang lain. Jauh dekatnya lokasi serta akses untuk menuju tempat tersebut sedikit banyak juga mempengaruhi minat kunjungan konsumen pada venue tersebut. Semakin dekat lokasi atau semakin berada di pusat kota atau semakin dekat dengan pusat keramaian lokasi tersebut, maka akan semakin memudahkan konsumen untuk menjangkau atau menuju lokasi tersebut.

Dalam hal ini Peacock coffee yang terletak di Jalan Gajahmada Semarang memberikan ketiga hal tersebut kepada semua konsumennya. Pemberian kualitas produk yang selalu terkontrol secara rutin untuk selalu memberikan pelayanan yang terbaik. Berada pada lokasi yang dianggap tepat dan tidak jauh dari pusat keramaian menjadi salah satu penunjang dari kedai kopi ini sehingga menjadi salah satu tujuan utama para pelanggannya untuk menikmati kopi yang dijual. Sedangkan fasilitas penunjang yang ada juga menjadikannya sebagai perhatian utama.

Namun kenyataan yang terjadi, permintaan konsumen selalu ingin mendapatkan yang terbaik dalam segala hal. Itulah sebabnya ada beberapa hal yang akan dijadikan sebagai acuan untuk mengukur seberapa puas konsumen pada segala sesuatu yang ada di kedai kopi tersebut. Faktor faktor yang dianggap mempengaruhi kepuasan konsumen, dianggap mampu untuk dijadikan langkah berikutnya untuk mencapai sebuah loyalitas konsumen.

Kualitas produk yang digadang gadang menjadi motor utama di kedai kopi ini ternyata juga menjadi salah satu bahasan juga dibeberapa review yang di tuliskan oleh para konsumen di media sosial yang mengupas review tentang Coffee Shop ini. Kualitas dianggap sangat berpengaruh dengan kepuasan konsumen, dikarenakan efek nya secara langsung yang didapatkan oleh konsumen setelah mereka membelinya. Kualitas produk yang terbaik masih dianggap menjadi sasaran utama dan menjadi alasan utama bagi para konsumen, khususnya para pecinta kopi. Namun rupanya Coffee Shop ini tidak hanya konsen menjual produk kopi, namun beberapa produk minuman lain dengan bahan dasar yang berbeda seperti halnya coklat, susu dan bahan lainnya.

Fasilitas menjadi faktor berikutnya yang turut berpengaruh terhadap kepuasan konsumen. Fasilitas dianggap sebagai faktor pendukung dari kualitas produk, dikarenakan kualitas produk membutuhkan fasilitas yang disebut sebagai pelengkap untuk menikmati kualitas produk yang disajikan. Terpenuhinya semua fasilitas yang dibutuhkan oleh konsumen akan sangat berpengaruh pada harapan akan keinginannya yang berdampak pada kepuasan yang harapanya tidak hanya pada kualitas produk yang disajikan saja.

Sebagai faktor pendukung berikutnya adalah lokasi, dimana sangat disadari lokasi sangat berpengaruh tidak hanya pada kepuasan, namun juga pada keputusan untuk membeli suatu produk. Jarak yang harus ditempuh, akses untuk menuju ke lokasi juga menjadi pertimbangan. Tercapainya sebuah kepuasan sedikit banyak juga ditentukan oleh lokasi dari sebuah tempat. Jauh dekatnya sebuah lokasi yang memberikan kualitas sebaik apapun, namun jika tidak didukung oleh lokasi yang memadahi dan mudah dijangkau pun akan menghambat untuk tercapainya sebuah kepuasan.

Peacock coffee yang dalam hal ini sebagi Coffee Shop yang sudah dianggap mapan di kota Semarang, pun menjadi sasaran para konsumen yang menjadi penikmat kopi pada umumnya untuk mendapatkan kepuasan dari apa yang mereka sudah bayarkan untuk produk yang ditawarkan. Kosumen merasa harus mendapatkan segala faktor yang mempu memuaskan mereka, dalam hal ini adalah kualitas produk, fasilitas yang diberikan dan lokasi yang memposisikan dimana Peacock coffee berada serta akses untuk menuju kesana. Dengan banyaknya konsumen yang berasal dari bermacammacam lapisan dan segmen, maka bisa di asumsikan Peacock coffee mampu diterima semua lapisan, tidak hanya karyawan, mahasiswa, pelajar maupun para pekerja lainnya. Dengan kompleksitas konsumen yang ada di Peacock Coffee ini, maka penulis tertarik untuk membuat penelitian dengan judul "Studi Kepuasan Konsumen Pada Peacock Coffee Gajahmada Semarang" 


\section{KAJIAN LITERATUR}

\section{Kualitas Produk}

Pengertian Produk (product) menurut Kotler (2009) adalah segala sesuatu yang dapat ditawarkan kepasar untuk mendapatkan perhatian, dibeli, digunakan atau dikonsumsi yang dapat memuaskan keinginan atau kebutuhan. Secara konseptual produk adalah pemahaman subyektif dari produsen atau sesuatu yang bisa ditawarkan sebagai usaha untuk mencapai tujuan organisasi melalui pemenuhan kebutuhan dan kegiatan konsumen, sesuai dengan kompetensi dan kapasitas organisasi serta daya beli pasar. (Tjiptono, 2008)

Berdasarkan beberapa definisi diatas, maka produk didefinisikan sebagai kumpulan dari atributatribut yang nyata maupun yang tidak nyata, termasuk didalamnya kemasan, warna, harga, kualitas dan merk ditambah dengan jasa dan reputasi penjualannya.(Kotler dan Armstrong, 2008), (Tjiptono, 2008)

Menurut Kotler dan Amstrong (2008), kualitas adalah karakteristik dari produk dalam kemampuan untuk memenuhi kebutuhan-kebutuhan yang telah ditentukan dan bersifat laten. Sedangkan menurut Garvin dan A. Dale Timpe (1990, dalam Alma, 2011), kualitas adalah keunggulan yang dimiliki oleh produk tersebut. Kualitas dalam pandangan konsumen adalah hal yang mempunyai ruang lingkup tersendiri yang berbeda dengan kualitas dalam pandangan produsen saat mengeluarkan suatu produk yang biasa dikenal kualitas sebenarnya.

Menurut Kotler dan Amstrong (2008) arti dari kualitas produk adalah "the ability of a product to perform its function, it includes the product's overall durability, reliability, precision, ease of operation and repair, and other valued atrributes." Yang artinya kemampuan sebuah produk dalam memperagakan fungsinya, hal itu termasuk keseluruhan durabilitas, reliabilitas, ketepatanm kemudahan pengoperasian dan reparasi produk juga atribut produk lainnya. (Zeithalm, 1988 dalam Kotler, 2009)

Konsumen senantiasa melakukan penilaian terhadap kinerja suatu produk, hal ini dapat dilihat dari kemampuan produk menciptakan kualitas produk dengan segala spesifikasinya sehingga dapat menarik minat konsumen unutk melakukan pembelian terhadap produk tersebut. Berdasarkan bahasan diatas dapat dikatakan bahwa kualitas yang diberikan suatu produk dapat mempengaruhi keputusan pembelian konsumen terhadap produk yang ditawarkan. a. Dimensi Kualitas Produk

Menurut Tjiptono (2008), kualitas mencerminkan semua dimensi penawaran produk yang menghasilkan manfaat bagi pelanggan. Kualitas suatu produk baik berupa barang atau jasa ditentukan melalui dimensi-dimensinya. Dimensi kualitas produk menurut Tjiptono (2008) adalah :

1. Performance (kinerja), berhubungan dengan karakteristik operasi dasar dari sebuah produk.

2. Durability (daya tahan), yang berarti berapa lama atau umur produk yang bersangkutan bertahan sebelum produk tersebut harus diganti. Semakin besar frekuensi pemakaian konsumen terhadap produk maka semakin besar pula daya produk.

3. Conformance to specification (kesesuaian dengan spesifikasi), yaitu sejauh mana karakteristik operasi dasar dari sebuah produk memenuhi spesifikasi tertentu dari konsumen atau tidak ditemukannya cacat pada produk.

4. Features (fitur), adalah karakteristik produk yang dirancang untuk menyempurnakan fungsi produk atau menambah ketertarikan konsumen terhadap produk.

5. Reliability (reliabilitas), adalah probabilitas bahwa produk akan bekerja dengan memuaskan atau tidak dalam periode waktu tertentu. Semakin kecil kemungkinan terjadinya kerusakan maka produk tersebut dapat diandalkan.

6. Aesthetic (estetika), berhubungan dengan bagaimana penampilan produk

7. Perceived quality (kesan kualitas), sering dibilang merupakan hasil dari penggunaan pengukuran yang dilakukan secara tidak langsung karena terdapat kemungkinan bahwa konsumen tidak mengerti atau kekurangan informasi atas produk yang bersangkutan

8. Serviceability, meliputi kecepatan dan kemudahan untuk direparasi, serta kompetensi dan keramahtamahan staf layanan.

\section{Fasilitas}

Fasilitas merupakan segala sesuatu yang memudahkan konsumen dalam menggunakan jasa perusahaan tersebut. Fasilitas adalah sumber daya fisik yang ada dalam sebelum suatu jasa dapat ditawarkan kepada konsumen (Tjiptono, 1997). (Kotler, 2005)

Menurut Tjiptono (2006) desain dan tata letak fasilitas jasa erat kaitannya dengan pembentukan presepsi pelanggan. Sejumlah tipe jasa, presepsi yang terbentuk dari interaksi antara pelanggan dengan fasilitas berpengaruh terhadap kualitas jasa tersebut di mata pelanggan. Faktor-faktor yang 
berpengaruh signifikan terhadap desain fasilitas jasa adalah sebagai berikut :

1. Sifat dan tujuan organisasi

Sifat suatu jasa seringkali menentukan berbagai persyaratan desainnya. Sebagai contoh desain rumah sakit perlu mempertimbangkan ventilasi yang memadai, ruang peralatan medis yang representatif, ruang tunggu pasien yang nyaman, kamar pasien yang bersih. Desain fasilitas yang baik dapat memberikan beberapa manfaat, diantaranya perusahaan mudah dikenali dan desain interior bisa menjadi ciri khas atau petunjuk mengenai sifat jasa didalamnya.

2. Ketersediaan tanah dan kebutuhan akan ruang atau tempat

Setiap perusahaan jasa membutuhkan lokasi fisik untuk mendirikan fasilitas jasanya. Dalam menentukan lokasi fisik diperlukan beberapa faktor, yaitu kemampuan finansial, peraturan pemerintah berkaitan dengan kepemilikan tanah dan pembebasan tanah, dan lain-lain.

3. Fleksibilitas

Fleksibilitas desain sangat dibutuhkan apabila volume permintaan sering berfluktuasi dan jika spesifikasi jasa cepat berkembang, sehingga resiko keuangan relatif besar. Kedua kondisi ini menyebabkan fasilitas jasa harus dapat disesuaikan dengan kemungkinan perkembangan di masa datang.

4. Faktor estetis

Fasilitas jasa yang tertata rapi, menarik akan dapat meningkatkan sikap positif pelanggan terhadap suatu jasa, selain itu aspek karyawan terhadap pekerjaan dan motivasi kerjanya juga meningkat. Aspek aspek yang peru ditata meliputi berbagai aspek. Misalnya tinggi langit-langit bangunan, lokasi jendela dan pintu, bentuk pintu yang beraneka ragam, dan dekorasi interior.

5. Masyarakat dan lingkungan sekitar

Masyarakat (terutama masalah sosial dan lingkungan hidup) dan lingkungan disekitar fasilitas jasa memainkan peranan penting dan berpengaruh besar terhadap perusahaan. Apabila perusahaan tidak mempertimbangkan faktor ini, maka kelangsungan hidup perusahaan bisa terancam.

6. Biaya kontruksi dan operasi

Kedua jenis biaya ini dipengaruhi desain fasililtas. Biaya kontruksi dipengaruhi oleh jumlah dan jenis bangunan yang digunakan. Biaya operasi dipengaruhi oleh kebutuhan energi ruangan, yang berkaitan dengan perubahan suhu.

\section{Lokasi}

Lokasi merupakan salah satu faktor dari situasional yang ikut berpengaruh pada keputusan pembelian. Dalam konsep pemasaran terdapat istilah yang dikenal dengan marketing mix atau bauran pemasaran yang terdiri dari produk, harga, promosi dan place atau lokasi usaha. Dalam marketing mix ini lokasi usaha dapat juga disebut dengan salutan distribusi perusahaan karena lokasi juga berhubungan langsung dengan pembeli atau konsumen atau dengan kata lain lokasi juga merupakan tempat produsen menyalurkan produknya kepada konsumen.(Buchari Alma, 2003), (Ujang Suwarman, 2004), (Kasmir, 2009) (Fandy Tjiptono, 2002) (Buchari Alma, 2003) (Utamu C.W, 2010) (Murfidin dan Mahfud, 2007).

Menurut Fandy Tjiptono (2006) dalam penelitian Aprih Santoso dan Sri Widowati (2011 : 183) variabel lokasi lebih memakai indikator berikut :Keterjangkauan lokasi, Kelancaran akses menuju lokasi, dan Kedekatan lokasi. Menurut Levi (2007:213) dalam jurnalnya Tezza Anwar (2007:137), ada beberapa karakteristik dari lokasi yang bisa mempengaruhi penjualan dari suatu toko, yaitu :

1. Alur lalu lintas yang melewati lokasi tersebut dan aksesibilitas menuju lokasi tersebut

2. Karakteristik dari lokasi

3. Biaya yang terkait dengan pemilihan lokasi tersebut

\section{Kopi}

Penemuan biji kopi dimulai sekitar tahun 800SM. Pada saat itu orang-orang di benua Afrika, khususnya bangsa Ethiopia mengkonsumsi biji kopi yang ducampurkan dengan lemak hewan dan anggur untuk memenuhi kebutuhan protein dan energi tubuh. Penemuan biji kopi terjadi secara tidak sengaja ketika penggembala bernama Khalid mengamati kawanan kambing gembalaannya yang tetap terjaga bahkan setelah matahari terbenam setelah memakan sejenis beri-berian, ia pun mencoba memasak dan memakannya, namun metode penyajiannya masih menggunakan meteode konvensional. Beberapa ratus tahun kemudian biji kopi dibawa melewati jalur merah dan tiba di Arab dengan metode penyajian yang lebih maju.

Bangsa Arab saat itu tidak hanya memasak biji kopi, tetapi merebus biji kpi untuk di ambil sarinya. Kepopuleran kopi pun turut meningkat seiring dengan penyebaran agama Islam pada saat itu. Pada masa itu belum ada budidaya tanaman kopi di luar daerah Arab karena bangsa Arab selalu mengekspor atau memasukan biji kopi yang tidak subur dengan cara memasak dan mengeringkannya terlebih dahulu, hal ini menyebabkan budidaya 
tanaman kopi tidak memungkinkan. Pada tahun 1600 seorang peziarah India bernama Baba Budan membawa biji kopi fertil keluar dari Makkah dan membudidayakannya diberbagai daerah di luar Arab.

Pada tahun 1615 biji kopi masuk pertama kali ke Eropa oleh seorang saudagar Venesia. Pasokan biji kopi yang dibawa ke Eropa berasal dari Turki, namun jumlah pasokan biji kopi ini tidak mencukupi kebutuhan pasar, oleh karena itu bangsa Eropa mulai membudidayakannya. Belanda adalah salah satu bagian negara Eropa yang pertama kali berhasil membudidayakannya pada tahun 1616, kemudian pada tahun 1690 biji kopi di bawa kepulau Jawa untuk pertamakalinya, pada saat itu Indonesia masih merupakan negara jajahan Belanda.

\section{Jenis-jenis biji Kopi}

Dari sekian banyak jenis biji kopi yang dijual di pasaran, hanya terdapat 2 jenis varietas utama, yaitu kopi arabika (Coffea arabica) dan Robusta (Coffea robusta). Masing-masing jenis kopi ini memiliki keunikannya masingmasing dan pasarnya sendiri.

a. Biji kopi Arabika

Biji kopi ini merupakan tipe kopi tradisional dengan cita rasa terbaik. Sebagian besar kopi yang ada, dibuat dengan menggunakan biji kopi Arabika. Kopi ini berasal dari Ethiopia dan sekarang telah dibudidayakan di berbagai belahan dunia. Tanaman kopi ini tumbuh di negara-negara beriklim tropis atau subtropis. Kopi arabika tumbuh pada ketinggian 600 - 2000 mdpl. Tanaman kopi ini dapat tumbuh hingga ketinggian 3 meter bila kondisi lingkungannya baik. Suhu tumbuh optimalnya adalah 18-26 derajat celcius. Biji kopi yang dihasilkan berukuran cukup kecil dan berwarna hijau hingga merah gelap. Kopi arabika banyak di tumbuhkan di Amerika Latin, Afrika tengah, Afrika Timur, India dan Indonesia.

b. Biji kopi Robusta

Biji kopi Robusta pertama kali ditemukan di kongo tahun 1898. Kopi Robusta diklasifikasikan sebagai kopi kelas 2, karena rasanya yang lebih pahit dari kopi Arabika, sedikit asam dan mengandung kafein dalam kadar yang jauh lebih banyak dbandingkan biji kopi Arabika. Selain itu, lingkup daerah tumbuh kopi Robusta lebih luas daripada kopi Arabika yang harus ditumbuhkan pada ketinggian tertentu. Kopi Robusta dapat ditumbuhkan dengan ketinggian 800mdpl. Kopi jenis ini lebih rawan terhadap serangan hama dan penyakit. Faktor ini yang menyebabkan kopi Robusta lebih murah. Kopi Robusta banyak ditumbuhkan di Afrika Barat, Afrika Tengah, Asia Tenggara dan Amerika Selatan.

c. Biji kopi Luwak

Jenis-jenis kopi yang lain merupakan turunan dari kopi Arabika dan Robusta. Disetiap daerah penghasil kopi biasanya memiliki keunikan masing-masing dan menjadikannya sebagai subvarietas. Salah satu jenis kopi yang terkenal adalah kopi luwak asli Indonesia. Kopi luwak merupakan kopi dengah harga jual tertinggi di dunia. Proses terbentuknya dan rasanya yang sangat unik menjadi alasan utama tingginya harga jual kopi jenis ini. Pada dasarnya, kopi ini merupakan kopi jenis Arabika, biji kopi ini kemudian dimakan oleh luwak atau sejenis musang. Akan tetapi, tidak semua bagian biji kopi ini dapat dicerna oleh hewan ini. Bagian dalam biji ini kemudian akan keluar bersama kotorannya. Karena telaj bertahan lama di dalam saluran pencernaan luwak, biji kopi ini telah mengalami fermentasi singkat oleh bakteri alami didalam perutnya yang memberikan cita rasa tambahan yang unik.

2. Jenis-jenis olahan minuman kopi

Minuman kopi yang ada saat ini sangatlah beragam jenisnya. Masing-masing jenis kopi yang ada memiliki proses penyajia dan pengolahan yang unik. Berikut ini adalah beberapa contoh minuman kopi yang umum dijumpai :

a. Kopi hitam (black coffee)

Merupakan hasil olahan ekstraksi langsung dari perebusan biji kopi yang disajikan tanpa penambahan perisa.

b. Espresso

Kopi yang dibuat dengan mengekstraksi biji kopi menggunakan uap panas pada tekanan tinggi dan menghasilkan rasa dan aroma kopi yang tajam tanpa harus membawa ampas kopi.

c. Latte (coffee latte)

Kopi espresso yang ditambahkan susu dengan rasio antara susu dan kopi adalah $3: 1$. 
d. Cafe au lait

Serupa dengan coffee latte tetapi menggunakan campuran kopi hitam dengan takaran kopi dan susu $1: 1$

e. Caffe macchiato

Kopi espresso yang ditambahkan susu rebus dengan rasio antara kopi dan susu 4 $: 1$

f. Cappucino

Kopi espresso dengan penambahan susu, krim, dan serpihan cokelat denga takaran yang seimbang

g. Dry capucino

Merupakan cappucino dengan sedikit krim dan tanpa susu

h. Frappe

Merupakan aspresso yang diolah dengan susu dan disajikan dingin.

i. Kopi instan

Berasal dari biji kopi yang dkeringkan dan digranulasi.

j. Kopi Irlandia (Irish coffee)

Merupakan kopi yang dicampur dengan wiskhkey.

k. Kopi tubruk

Kopi asli Indonesia yang dibuat dengan memasak biji kopi bersamaan dengan gula

1. Melya

Sejenis kopi dengan penambahan bubuk cokelat dan madu.

m. Kopi moka

Serupa dengan cappucino dan latte, tetapi dengan penambahan sirup cokelat.

n. Oliang

Kopi khas Thailand yang dimasak dengan jagung, kacang kedelai dan wijen

o. Americano

Kopi yang berbahan dasar espresso, biasanya lebih encer dan disajikan dalam gelas besar.

p. Doppio (Double shoot)

Kopi yang memiliki kandungan espresso dua kali lebih banyak dibandingkan kopi biasa dan mengandung kopi yang amat pekat, serta tergolong berat bagi mereka yang bukan peminum kopi.

q. Marocchino

Olahan kopi yang berbahan dasar espreso dengan paduan sedikit susu panas dan coklat bubuk

r. Ganita di cafe con panna

Kopi espresso yang di bekukan, lalu dihancurkan menjadi serpihan-serpihan es dalam sebuah gelas, disajikan dengan whiped cream di atasnya dan taburan coklat.

s. Freedo

Biasanya disebut juga dengan iced coffee adalah sebuah kopi yang disajikan dengan es batu dan biasanya ditambahkan sedikit susu dan gula.

\section{Coffee shop}

Adalah sebuah restoran yang pada awalnya hanya menyediakan tempat khusus untuk minum kopi dan teh secara cepat, namun seiring berjalannya waktu dan kebutuhan pelanggan yang sangat bervariasi maka kedai kopi ini juga mulai menyediakan makanan ringan sebagai teman minum kopi. Coffee shop dikategorikan ke dalam restoran informal dan biasanya buka untuk 24 jam di sebagian besar coffee shop yang ada di hotel. Coffee shop juga merupakan tempat orang-orang berkumpul menikmati kopi. Di kebanyakan coffee shop menyediakan berbagai macam pilihan dan tipe kopi yang sangat berbeda. Pilihan kopinya mulai dari plain coffee hingga pilihan kopi dengan rasa yang dikhususkan sesuai dengan minat terbanyak yag digemari konsumen. Pilihan ini amat jarang ditemukan di restoran dan lokasi lainnya, karena coffee shop ini merupakan jenis restoran yang menjual produk kopi sebagai produk utama dari tempat ini.

Banyak kedai kopi saat ini sudah dilengkapi dengan pilihan menu makanan ringan sebagai pasanga ideal, cara penyajiannya cukup cepat. Coffee shop umumnya menjad pilihan bagi para pelaku bisnis yang melawatkan makan pagi/siangnya, karena tempat ini akan menyajikan makanan seara cepat sesuai dengan keinginan konsumenyang tidak ingin semua disajikan dengan cepat.

Untuk beberapa tempat seperti ini d hotel, coffee shop menjadi bagian dari sebuah perusahaan besar dimana hanya ada sedikit pilihan tipe kopi dan mereka akan memperhitungkan mengenai pilihan biji kopi terbaik yang akan digunakan mereka untuk coffee shop tersebut. Selain itu mereka akan lebih teliti dalam memiliki mesin terbaik yang akan digunakan untuk membuat kopi. Kopi yang diharuskan harus memiliki rasa yang menarik dan mewah, karena mereka mengutamakan penyajian untuk kedai kopi yang berada di hotel.

Coffee shop dilengkapi dengan fasilitas internet/wifi untuk menunjang kelancaran kebutuhan konsumen yang senang menghabiskan waktu di kedai kopi. Dimana sangatlah tidak biasa untuk tamu hanya meminta kode wifi, mereka akan secara tidak langsung memesan kopi dan konsumen mengharapkan barista akan membuatkan kopi 
dengan desain yang menarik sesuai dengan harga yang telah dibayar.

Sejarah coffee shop ini berasal dari Amerika dimana ciri pelayanan dan penyajiannya yaitu secara cepat, makanan sudah diporsikan dalam satu piring atau yang lebih dikenal dengan Ready on plate dengan istilah pelayanannya yaitu American Service. Sejarah awal kopi ini ada di tahun 1475. Kiva Han adalah nama kedai kopi pertama yang berlokasi di Constantinopel (Istanbul) Turki. Kopi menjadi produk penting disaat itu di Turki. Uniknya, kopi dianggap legal untuk seorang wanita menceraikan suaminya jika suaminya tidak mampu menyediakan cukup kopi dirumahnya. Kopi Tukri sangat kental, hitam dan ampasnya tidak disaring.

Ide awal mulanya untuk menambah cita rasa kopi dengan pemanis atau krim bermula di tahun 1529 setelah coffee shop pertama di Eropa didirikan. Vienna pernah diinfasi pasukan Turki yang meninggalkan banyak karung kopi ketika mereka kalah dan kabur melarikan diri. Lalu Franz Georg Kolschitzky mengklaim kopi tersebut sebagai rampasan perang dan mendirikan Coffee Shop. Ia adalah orang satu-satunya yang mengetahui tentang karakter biji kopi yang sesungguhnya. Idenya adalah dengan menyaring kopi dengan menambahkan susu dan gula untuk memperhalus cita rasa kopi. Minuman ini sangat digemari dan ketika Coffee Shop ini mulai menjual kue manis dan panganan lainnya, popularitasnya semakin meningkat.

Keberadaan kopi terus menyebar dengan adanya Coffee Shop pertama di daerah Britania (1652). Meski semakin populer, ide kedai kopi sampai ke Inggris langsung dari Turki. Pedagang Inggris yang menjaga barang-barang turki kemudian membuka bisnis mereka sendiri. The Coffee Shop Turk's Head akhirnya lahir.

Istilah kata "tips" pertama kali muncul di Coffee Shop Inggris yang diartikan sebagai gratifikasi. Sebuah toples bertuliskan "guna menjamin pelayanan yang cepat", diletakkan di meja counter. Setiap konsumen yang datang memasukan koin ke dalam toples tersebut untuk dapat dilayani dengan cepat. Lalu orang Inggris memberi nama Coffee Shop mereka "Penny University" karena harga kopi saat itu memang sangat mahal dan banyak bisnis kelas atas yang didirikan disitu. Tetapi pada kenyataannya bisnis Coffee Shop kecil yang dijalankan oleh Edward Lloyd tahun 1668 justru masih bertahan sampai saat ini, sebagai perusahaan asuransi Lloyd of London. Ide ini semakin menyebar di Eropa, Italia tahun 1654, Paris tahun 1672 dan Jerman tahun 1673.

Pada tahun 1946, mulai muncul mesin pembuat espresso. Gaggia menciptakan mesin tersebut secara komersial yang jauh lebih mudah dan aman digunakan dibanding model awal. Coffee Shop Gaggia pertama berada di Italia. Dari situ era modern kopi telah dimulai. Tim Horton merupakan contoh yang bagus untuk Coffee Shop yang popular, selain menyajikan makanan berat, mereka terkenal di berbagai negara dengan kopi mereka yang nikmat. Namun hal ini tidak dapat diklasifikasikan sebagai Coffee Shop karena mereka tidak memiliki espresso sebagai bahan dasar pembuatan kopi. Satu lagi kedai kopi yang paling terkenal di seluruh dunia adalah Starbucks, memiliki lebih dari 8000 kedai cabang diseluruh dunia dan pertama kali dibuka di Seattle pada tahun 1971.

\section{Kepuasan Pelanggan}

Swan, et al (1980) dalam Tjiptono (2008) mendefinisikan kepuasan pelanggan sebagai evaluasi secara sadar atau penilaian kognitif menyangkut apakah kinerja produk relatif bagus atau jelek atau apakah produk bersangkutan cocok atau tidak cocok dengan tujuan pemakaiannya.

Menurut Kotler (2009), kepuasan pelanggan adalah hasil yang dirasakan oleh pembeli yang mengalami kinerja sebuah perusahaan yang sesuai dengan harapannya. Pelanggan merasa puas kalau harapan mereka terpenuhi, dan merasa amat gembira kalau harapan mereka terlampaui. Pelanggan yang puas cenderung tetap loyal lebih lama, membeli lebih banyak, kurang peka terhadap perubahan harga dan pembicaraanya menguntungkan perusahaan.

Dalam rangka menciptakan kepuasan pelanggan, produk yang ditawarkan organisasi/perusahaan harus berkualitas. Kualitas mencerminkan semua dimensi penawaran produk yang menghasilkan manfaat bagi perusahaan.

Customer satisfaction adalah perasaan senang atau kecewa yang dirasakan seseorang yang berasal dari perbandingan antara kesannya terhadap kinerja (hasil) suatu produk dan harapan-harapannya, dengan kata lain kepuasan sebagai evaluasi paska konsumsi dimana suatu alternatif yang dipilih setidaknya memenuhi atau melebihi harapan (Kotler, 2009).

Konsumen yang merasa puas adalah konsumen yang menerima nilai tambah yang lebih dari perusahaan. Memuaskan konsumen tidak hanya berarti memberikan tambahan produk atau jasa, pelayanan ataupun sistem yang digunakan (Kotler dan Keller, 2008). Kepuasan pelanggan merupakan suatu hal yang sangat berharga demi mempertahankan keberadaan pelanggan tersebut untuk tetap berjalannya bisnis atau usaha (Alma, 2011). 
Dalam konsep kepuasan pelanggan terdapat dua elemen yang mempengaruhi, yaitu harapan dan kinerja. Kinerja adalah persepsi konsumen terhadap apa yang diterima setelah mengkonsumsi produk. Harapan adalah perkiraan konsumen tentang apa yang akann diterima apabila ia mengkonsumsi produk (barang atau jasa).

Kepuasan pelanggan merupakan fungsi dari kualitas pelayanan dikurangi harapan pelanggan (Zeithaml dan Bitner, 2008) dengan kata lain pengukuran kepuasan konsumen dirumuskan sebagai berikut :

\section{Service qulity $<$ Expectation}

Bila ini terjadi, dapat dikatakan bahwa pelayanan yang diberikan perusahaan buruk. Selain tidak memuaskan juga tidak sesuai dengan harapan pelanggan. Jika service quality yang diberikan perusahaan lebih kecil dari expectation pelanggan, maka akan mengakibatkan ketidakpuasan terhadap pelanggan.

2. Service Quality $=$ Expectation

Bila ini terjadi dapat dikatakan bahwa pelayanan yang diberikan tidak ada keistimewaan. Jika nilai kualitas pelayanan yang diberikan perusahaan sama dengan harapan pelanggan, maka muncul kepuasan yang biasa diinginkan pelanggan.

3. Service quality > Expectation

Bila ini terjadi dapat dikatakan bahwa pelanggan merasakan pelayanan yang diberikan oleh perusahaan tidak hannya sesuai dengan kebutuhan, namun sekaligus memuaskan dan menyenangkan. Jika kualitas pelayanan lebih besar dari harapan yang diinginkan pelanggan, maka akan membuat kepuasan pelanggan sangat luar biasa. Pelayanan ketiga ini disebut dengan pelayanan prima (excelent service)yang selalu diharapkan oleh pelanggan.

Tingkat kepuasan konsumen dapat ditentukan berdasar pada lima (5) faktor utama yang harus diperhatikan oleh sebuah perusahaan (Irawan, 2009) yaitu :

1. Kualitas produk

Konsumen akan merasa puas apabila hasil evaluasi mereka menunjukan bahwa produk yang mereka gunakan berkualitas.

2. Kualitas pelayanan

Konsumen akan merasa puas apabila mereka mendapatkan pelayanan yang sesuai yang diharapkan terutama untuk industri jasa.

3. Emosional

Konsumen akan merasa bangga dan mendapatkan keyakinan bahwa orang lain akan kagum terhadap konsumen tersebut apabila menggunakan merek tertentu yang cenderung mempunyai tingkat kepuasan.

4. Harga

Produk yang mempunyai kualitas yang sama tetapi menetapkan harga yang relatif murah akan memberikan nilai lebih tinggi kepada konsumennya.

5. Biaya

Konsumen tidak perlu mengeluarkan biaya tambahan atau tidak perlu membuang waktu untuk mendapatkan suatu produk atau jasa, cenderung puas terhadap produk atau jasa tersebut.

Menurut Sofyan Assauri (2004 dalam Alma, 2011) mengemukakan bahwa tingkat kualitas ditentukan oleh beberapa faktor, antara lain :

1. Fungsi suatu barang

Kualitas yang hendaknya dicapai dengan fungsi untuk apa barang tersebut digunakan atau dibutuhkan tercermin pada spesifikasi dari barang tersebut seperti tahan lamanya, kegunaannya, berat, bunyi, mudah atau tidaknya perawatan dan kepercayaannya.

2. Wujud Luar

Salah satu faktor yang penting dan sering dipergunakan oleh konsumen dalam melihat suatu barang pertama kalinya, untuk menentukan kualitas barang tersebut, adalah wujud luar barang itu. Faktor wujud luar yang terdapat pada suatu barang tidak hanya terlihat dari bentuk, tetai juga dari warna, susunan dan hal-hal lainnya.

3. Biaya barang tersebut

Umumnya biaya dan harga suatu barang akam menentukan kualitas barang tersebut. Hal ini terlihat dari barang-barang yang mempunyai biaya atau harga yang mahal, dapat menunjukan bahwa kualitas barang tersebut relatif lebih baik. Berdasarkan penjelasan diatas, dapat disimpulkan bahwa faktor-faktor yang mempengaruhi kepuasan pelanggan adalah performa produk dan jasa, kualitas produk, kualitas pelayanan,emosional, harga dan nilai yang sesuai dengan harapan pelanggan.

\section{METODE PENELITIAN}

Penelitian yang digunakan adalah penelitian kuantitatif, peneliti dapa menentukan hanya beberapa variabel saja dari obyek yang diteliti dan kemudian dapat membuat instrumen yang di ukur (Sugiyono, 2009).

Pengumpulan data primer merupakan pengumpulan data melalui kuesioner secara personal. Peneliti berhubungan langsung dengan responden dan memberikan penjelasan seperlunya 
dan kuesioner dapat langsung dikumpulkan setelah selesai dijawab oleh responden. Pertanyaan yang disajikan dalam kuesioner berupa pertanyaan tertutup dam pertanyaan terbuka. Pertanyaan tertutup dibuat dengan menggunakan skala interval. Sedangkan pertanyaan terbuka diperlukan untuk mendukung secara kualitatif dari data kuantitatif yang diperoleh. Diukur dengan skala likert dari 1 sampai dengan 5 dengan indikator kepuasan konsumen, kualitas produk, kebaikan fasilitas, dan kenyamanan lokasi.

Populasi dalam penelitian ini adalah tamu pengunjung Peacock Coffee Gajahmada Semarang. Populasinya merupakan infinity karena jumlahnya tidak diketahui pasti. Sampel merupakan bagian dari subjek yang sesungguhnya menjadi suatu penelitian. Teknik pengambilan sampel menggunakan metode Accidental sampling yang dilakukan dengan memperoleh data dari sekumpulan populasi, lalu secara insidental atau secara kebetulan saja dengan tidak menggunakan perencanaan tertentu. Sampel diambil 87 orang.

Kepuasan konsumen Peacocok Coffee dipengaruhi oleh variabel kualitas produk, fasilitas dan lokasi di mana untuk kualitas produk, fasilitas dan lokasi merupakan variabel bebas, sedangkan kepuasan konsumen merupakan variabel terikat. Untuk mengetahui besarnya pengaruh kualitas produk, fasilitas dan lokasi terhadap kepuasan konsumen maka alat analisis yang dipergunakan adalah uji validitas, uji reliabilitas, regresi linier berganda, uji t, uji F, dan koefisien determinasi.

\section{Metode Pengumpulan Data}

Pengumpulan data dalam penelitian ini adalah sebagai berikut:

\section{Kuesioner}

Dalam penelitian ini, data diperoleh dengan menyebarkan kuesioner.Kuesioner di desain sedemikian rupa sehingga diharapkan semua responden dapat menjawab semua pertanyaan. Kuesioner adalah daftar pertanyaan yang disusun dalam bentuk tulisan yang memerlukan jawaban dari responden untuk mengumpulkan sejumlah data. Kuesioner yang digunakan dalam penelitian ini adalah berupa pertanyaan tertutup dan terbuka. Pertanyaan tertutup dibuat dengan menggunakan skala interval, untuk memperoleh data yang jika diolah menunjukkan pengaruh atau hubungan antara variabel. Sedangkan pertanyaan terbuka diperlukan untuk mendukung secara kualitatif dari data kuantitatif yang diperoleh dan akhirnya dapat digunakan sebagai implikasi manajerial. Jenis pertanyaan dalam kuesioner tersebut adalah pertanyaan berstruktur. Pertanyaan berstruktur adalah pertanyaan yang dibuat sedemikian rupa sehingga responden dibatasi dalam memberi jawaban pada beberapa alternatif saja atau kepada satu jawaban saja. Responden yang dipilih adalah responden yang sesuai dengan kriteria pada penarikan sampel (Stanley, 2009).

\section{Metode Analisis Data}

1. Untuk mengetahui proses pengambilan keputusan pembelian oleh konsumen dianalisis secara deskriptif dengan melihat persentase masing-masing tahapan.

2. Untuk menganalisis tingkat kepuasan konsumen digunakan analisis deskriptif dengan melihat persentase tingkat kepuasan dan rentang skala

Untuk menganalisis pengaruh kualitas produk, fasilitas, dan lokasi secara bersama-sama terhadap kepuasan konsumen di Peacock Coffee Gajahmada Semarang. Dalam penelitian ini menggunakan Penelitian tahap pertama yang dilakukan adalah penentuan dan penggolongan atribut-atribut kepuasan konsumen untuk kualitas produk, fasilitas dan lokasi, serta penyusunan kuesioner. Setelah menyusun kuesioner, dilakukan pengujian reliabilitas dan validitas terhadap kuesioner tersebut. Pengujian reliabilitas dan validitas ini sangat penting dilakukan karena bertujuan untuk mengetahui sejauh mana suatu alat ukur dapat dipercaya serta sejauh mana alat ukur dapat mengukur yang ingin diukur. Apabila setelah diuji kuesioner ternyata tidak reliabel dan tidak valid, maka dilakukan revisi terhadap kuesioner dan pengujian kembali. Apabila kuesioner yang telah diuji ternyata reliabel dan valid maka penelitian dilanjutkan ke tahap selanjutnya yaitu penentuan populasi dan sampel menggunakan metode Slovin. Selanjutnya data dikumpulkan dan dianalisis menggunakan program SPSS dan Microsoft Excel. Setelah analisis data, akan didapatkan atributatribut yang dianggap penting, atribut prioritas serta tingkat kepuasan konsumen terhadap produk dan pelayanan.Isi diketik dengan font 10 dan spasi 1

\section{HASIL PENELITIAN DAN PEMBAHASAN}

1. Hasil uji validitas dan reliabilitas

Hasil pengujian validitas dan reliabilitas instrument menunjukkan bahwa semua butir pertanyaan valid dan reliabel.

2. Analisis Regresi linier berganda Hasil analisis regresi linier berganda 
Tabel 1. Output Regresi Linier Berganda

\begin{tabular}{ccccc} 
Koefisien & B & Beta & t & Sig \\
\hline (Constant) & 0.807 & & 1.467 & 0.146 \\
\hline $\begin{array}{c}\text { Kualitas } \\
\text { Produk }\end{array}$ & 0.26 & 0.299 & 6.331 & 0.000 \\
\hline Fasilitas & 0.281 & 0.296 & 5.081 & 0.000 \\
\hline $\begin{array}{c}\text { Lokasi } \\
\text { Sumber: Data primer yang diolah, } 2018\end{array}$
\end{tabular}

$Y=0.807+0,26 X_{1}+0,281 X_{2}+0,401 X_{3}$

Dari persamaan di atas dapat dijelaskan sebagai berikut :

Konstanta (a) $=0.807$ berarti apabila variable kualitas produk, fasilitas, dan lokasi dianggap tidak, maka kepuasan konsumen sebesar 0.807 .

$\beta_{1}=0.26$ artinya apabila terjadi peningkatan setiap satu satuan pada variable kualitas produk $\left(\mathrm{X}_{1}\right)$, maka kepuasan konsumen akan naik sebesar 0.26 satuan dengan asumsi variable fasilitas dan variabel lokasi konstan

$\beta_{2}=0.281$ artinya apabila terjadi peningkatan setiap satu satuan pada variable Fasilitas $\left(\mathrm{X}_{2}\right)$, maka kepuasan konsumen akan naik sebesar 0.281 satuan dengan asumsi variable Kualitas produk dan variabel lokasi konstan

$\beta_{3}=0.401$ artinya apabila terjadi peningkatan setiap satu satuan pada variable lokasi $\left(\mathrm{X}_{3}\right)$, maka kepuasan konsumen akan naik sebesar 0.401 satuan dengan asumsi variable kualitas produk dan variable fasilitas konstan

3. Uji t

Hasil perhitungan uji $t$ secara parsial menunjukan bahwa variable kualitas produk, fasilitas dan lokasi terbukti secara statistic berpengaruh signifikan terhadap variable kepuasan konsumen.

4. $\mathrm{Uji} F$

Tabel 2. Perhitungan uji F

\begin{tabular}{clccccc}
\multirow{2}{*}{ Model } & $\begin{array}{c}\text { Sum of } \\
\text { Squares }\end{array}$ & df & $\begin{array}{c}\text { Mean } \\
\text { Square }\end{array}$ & F & Sig. \\
\hline 1 & Regression & 92.444 & 3 & 30.815 & 133.917 & $.000^{\mathrm{b}}$ \\
\cline { 2 - 7 } & Residual & 19.329 & 84 & .230 & & \\
\cline { 2 - 7 } & Total & 111.773 & 87 & & &
\end{tabular}

Sumber: Data primer yang diolah, 2018
Hasil perhitungan uji $\mathrm{F}$ menunjukan bahwa ada pengaruh yang signifikan variable independent yaitu kualitas produk $\left(\mathrm{X}_{1}\right)$, fasilitas $\left(\mathrm{X}_{2}\right)$ dan lokasi $\left(\mathrm{X}_{3}\right)$ secara simultan terhadap kepuasan konsumen.

5. Koefisiensi Determinasi $\left(\mathrm{R}^{2}\right)$

Tabel 3. Model Summary

\begin{tabular}{|c|c|c|c|c|}
\hline Model & $\mathrm{R}$ & $\begin{array}{c}\mathrm{R} \\
\text { Square }\end{array}$ & $\begin{array}{l}\text { Adjusted } \\
\text { R Square }\end{array}$ & $\begin{array}{l}\text { Std. Error of } \\
\text { the Estimate }\end{array}$ \\
\hline 1 & $.909^{\mathrm{a}}$ & .827 & .821 & .480 \\
\hline
\end{tabular}

Nilai $\mathrm{R}^{2}$ sebesar 0.821 . Artinya $82.1 \%$ kepuasan konsumen dapat dijelaskan oleh variable kualitas produk, fasilitas dan lokasi sedangkan 17.9 $\%$ dijelaskan oleh variable lain yang tidak diteliti.

6. Pembahasan

Berdasarkan hasil pengujian hipotesis dengan analisis regresi linier berganda, hasil analisis pengaruh kualitas produk, fasilitas dan lokasi terhadap kepuasan konsumen di Peacock Coffee Gajahmada Semarang, variabel kepuasan produk, fasilitas dan lokasi memiliki pengaruh signifikan positif terhadap kepuasan konsumen. Variabel lokasi mempunyai variabel paling dominan terhadap kepuasan konsumen dibandingkan dengan variabel yang lain.

\section{PENUTUP}

Hasil analisis data dalam penelitian mendukung semua hipotesis yang diajukan. Kualitas produk, fasilitas dan lokasi mempunyai pengaruh secara parsial maupun simultan terhadap kepuasan konsumen dan variabel lokasi mempunyai pengaruh dominan.

\section{SARAN}

- Sebaiknya kenyamanan dan pelayanan terus ditingkatkan agar selalu meningkatkan kepuasan konsumen,

- Hendaknya menambahkan fasilitas parkir. Apalagi ketika saat ramai banyak pengunjung harus memarkirkan kendaraan cukup jauh,

- Diperlukan menambahan AC untuk meningkatkan kenyaman konsumen, apalagi pada saat jumlah pengunjung meningkat karena akan berefek pada ketidaknyaman yang membuat kepuasan konsumen. 


\section{DAFTAR PUSTAKA}

DelVecchio,D, dan D.Smith.(2005),Brand Extension Price Premiums:The Effect of Perceived Fit and Extension Product Category Risk,Journal of Academy of Marketing Science 33

Handi, Irawan. 2002. 10 Prinsip Kepuasan Pelanggan. Jakarta : Elex Media Komputindo.

https://id.wikipedia.org/wiki/Sejarah_kopi

https://www.sasamecoffee.com/kopipedia/sejarahdan-jenis-kopi/

https://coffeeland.co.id/sejarah-kopi/

https://majalah.ottencoffee.co.id/hal-hal-pentingsebelum-memulai-coffee-shop/

https://majalah.ottencoffee.co.id/hal-hal-pentingsebelum-memulai-coffee-shop/

https://en.wikipedia.org/wiki/Coffeehouse

Kotler, P. dan Keller K.L., 2008, Manajemen Pemasaran, Jakarta: Indeks.

Kotler, Philip, Alih Bahasa A.B. Susanto. 2005. Manajemen Pemasaran di Indonesia, Analisis, Perencanaan, Implementasi dan Pengendalian. Jakarta : Penerbit Salemba Empat.

Kotler, Philip. 2009. Manajemen Pemasaran, Jilid 2, Edisi 13. Alih Bahasa Benyamin Molan. Jakarta: Prehallindo.

Lau, G.T. dan Lee, S.H.. 1999. Customer's Trust in a Brand and the Link to brand Loyallity. Journal of Market Focused Management, Vol. 4.

Parasuraman, A, dan Valeire A. Zeithaml, dan Leonard Berry. 2005. Reassesment of Expectations as A Comparison Standart in Measuring Service Quality: Implications for Futher Research.Journal of Marketing, Vol. 58, January. 111- 124.

Rangkuti, Freddy. 2006. Measuring Customer Satisfaction, (Teknik Mengukur dan Strategy Meningkatkan Kepuasan
Pelanggan), Jakarta: Gramedia Pustaka Utama.

Sulistino, Ari Budi. 2010. Pengaruh Kualitas Pelayanan, Fasilitas dan Lokasi terhadap Keputusan Menginap. Semarang: Fakultas Ekonomi Universitas Diponegoro.

Tjiptono, F.. 2002. Strategi Pemasaran, edisi 11. Yogyakarta: Andi Offset.

Umar, Husein. 2003. Metodologi Penelitian. Jakarta: Gramedia Pustaka Utama.

\section{Profil Penulis}

1. Tuwuh Adhistyo W., S.E., M.Par Keilmuan Manajemen, Sekolah Tinggi Ilmu Ekonomi Pariwisata (STIEPARI) Semarang, Bendan Ngisor, Semarang - 50233

Email: zefanya.adhistyo@gmail.com.

2. Krisnawati Setyaningrum Nugraheni, S.TP., M.M. Keilmuan Manajemen, Sekolah Tinggi Ilmu Ekonomi Pariwisata (STIEPARI) Semarang, Bendan Ngisor, Semarang - 50233 Email: krisnawati.stiepari@gmail.com 